\title{
Treatment with Depleting CD4 Monoclonal Antibody Results in a Preferential Loss of Circulating Naive T Cells but Does Not Affect IFN- $\gamma$ Secreting TH1 Cells in Humans
}

\author{
Martin H.G. Rep, ${ }^{\star}$ Bob W. van Oosten, ${ }^{\ddagger}$ Marijke T.L. Roos, ${ }^{\star}$ Herman J. Adèr, ${ }^{\S}$ Chris H. Polman, ${ }^{\ddagger}$ and René A.W. van Lier* \\ *Department of Clinical Viro-Immunology, Central Laboratory of The Netherlands Red Cross Blood Transfusion Service and \\ Laboratory of Experimental and Clinical Immunology of the University of Amsterdam, Amsterdam; ${ }^{\ddagger}$ Department of Neurology, Free \\ University Hospital, Amsterdam; and ${ }^{\S}$ Department of Epidemiology and Biostatistics, Faculty of Medicine, Free University, Amsterdam, \\ The Netherlands
}

\begin{abstract}
$\mathrm{CD}^{\text {pos }}$ TH1 T cells are considered to play a central role in a number of human autoimmune diseases such as rheumatoid arthritis (RA) and multiple sclerosis. Experimental treatment protocols aimed at selectively eliminating $\mathrm{CD}^{\text {pos }} \mathrm{T}$ cells thus far have yielded disappointing clinical results. Here we analyzed phenotype and function of circulating $T$ cells in multiple sclerosis patients treated with the chimeric CD4 $\mathrm{mAb}$ cM-T412 in a randomized, double-blind, placebo-controlled, magnetic resonance imaging-monitored phase II trial. Treatment resulted in a long-lasting depletion of CD4 ${ }^{\text {pos }}$ $\mathrm{T}$ cells but did not affect $\mathrm{CD}^{\text {pos }} \mathrm{T}$ cell numbers. Analysis of $\mathrm{CD}^{\text {pos }}$ subpopulations showed that unprimed, CD45RA ${ }^{\text {pos/ }}$ $\mathrm{R}^{\text {neg }}$ lymphocytes were approximately three times more sensitive to the mAb than primed, CD45RA ${ }^{\text {neg }} / \mathrm{R}^{\text {pos }} \mathrm{T}$ cells. Notably, within the CD45RA ${ }^{\text {pos }}$ subset, T cells with phenotypic evidence of prior activation, i.e., expressing Fas, were relatively insensitive to cM-T412, compared with Fas ${ }^{\text {neg }}$ cells. Remarkably, while a decrease in the number of IL-4-producing T helper 2 (TH2)-type cells in the anti-CD4 treated group was observed, numbers of IFN- $\gamma$-producing $T$ helper 1 (TH1)-type cells remained stable, resulting in a significant increase in the $\mathrm{TH} 1 / \mathrm{TH} 2$ ratio. Our data show that treatment with depleting CD4 mAb does not eliminate the cells most strongly involved in the disease process, i.e., primed, IFN- $\gamma$-producing TH1-type cells, and may therefore give an explanation for the lack of beneficial clinical effects of depleting CD4 mAb in human chronic autoimmune disease. (J. Clin. Invest. 1997. 99:2225-2231.) Key words: CD4 antibodies, monoclonal $\bullet$ autoimmune diseases therapy $\bullet$ multiple sclerosis • T lymphocyte subsets $\bullet$ Th1 cells
\end{abstract}

\section{Introduction}

$\mathrm{CD}^{\text {pos }} \mathrm{T}$ cells, which recognize peptide fragments that are presented in the groove of major histocompatibility complex class II molecules (1), orchestrate cellular and humoral immune re-

Address correspondence to Dr. R.A.W. van Lier, Dept. of Clinical Viro-Immunology, Central Laboratory of The Netherlands Red Cross Blood Transfusion Service, Plesmanlaan 125, 1066 CX Amsterdam, The Netherlands. Phone: 31-20-512-3317; FAX: 31-20-512-3310.

Received for publication 26 December 1996 and accepted in revised form 19 February 1997.

J. Clin. Invest.

(C) The American Society for Clinical Investigation, Inc.

0021-9738/97/05/2225/07 \$2.00

Volume 99, Number 9, May 1997, 2225-2231 actions through the secretion of immunoregulatory cytokines and via cell-cell contact $(2,3)$. Based on cytokine production capacity, distinct types of differentiated helper $(\mathrm{H}) \mathrm{CD}^{\mathrm{pos}} \mathrm{T}$ cells are identified (4). Typically, TH1-type cells secrete IFN- $\gamma$ and $\mathrm{TNF}-\alpha$ and are involved in cell-mediated immunity, whereas TH2-type cells secrete IL-4 and IL-5 and exert their primary function in humoral immune reactions $(5,6)$. Normally, a balance exists between these two helper $\mathrm{T}$ cell subsets, which is in a considerable degree maintained by cross-regulatory mechanisms. IL-4 downregulates development of TH1-type cells, and vice versa IFN- $\gamma$ suppresses the TH2-type response (7). Autoimmune diseases are believed to be dependent on activation of TH1-type cells which is not sufficiently counterbalanced by TH2-type cells $(8,9)$. Indeed, a number of experimental animal models have shown that (auto)antigen reactive CD4pos TH1-type cells are of crucial importance for disease induction and disease progression (10-12). In accordance with this notion, in vivo depletion of $\mathrm{CD} 4^{\text {pos }} \mathrm{T}$ cells interferes with disease induction in experimental allergic encephalomyelitis (13-16), adjuvant arthritis (17), collagen-induced arthritis (18), experimental autoimmune glomerulonephritis (19), experimental antiphospholipid syndrome, and systemic lupus erythematosus $(20)$.

Also in human autoimmune diseases a pivotal role for CD4 ${ }^{\text {pos }} \mathrm{T}$ cells has been postulated $(21,22)$ and experimental trials aimed at specifically attacking these cells with depleting $\mathrm{CD} 4 \mathrm{mAb}$ have been initiated. Although in open studies more or less promising results have been obtained with $\mathrm{CD} 4 \mathrm{mAb}$ treatment of rheumatoid arthritis (RA) (23-25), systemic lupus erythematosus (26), Crohn's disease (26a), and multiple sclerosis (MS) ${ }^{1}$ patients (27-29), in double-blind, placebo-controlled, phase II trials with RA patients the efficacy appeared to be absent or very low $(30,31)$. Recently, absence of therapeutic effect was also documented in a randomized, doubleblind, placebo-controlled, magnetic resonance imaging (MRI)monitored phase II trial in which MS patients were treated with the chimeric CD4 mAb cM-T412 (32). As was also shown in earlier studies $(28,29)$, in this trial, a significant and longlasting depletion of CD4pos $\mathrm{T}$ cells was found in $\mathrm{CD} 4 \mathrm{mAb}-$ treated patients. However, no effect could be demonstrated on the primary measure of efficacy, the number of active lesions on monthly gadolinium enhanced MRI over 9 mo.

To examine the cause for therapeutic ineffectiveness of depleting CD4 mAb in humans, we here analyzed consequences of CD4 mAb treatment on phenotypical and functional characteristics of circulating $\mathrm{T}$ cells in MS patients. Our data show

1. Abbreviations used in this paper: MRI, magnetic resonance imaging; MS, multiple sclerosis; PE, phycoerythrin. 
that the absence of therapeutic success coincides with a specific inability of the antibody to delete primed, IFN- $\gamma$-producing $\mathrm{T}$ cells.

\section{Methods}

Study design. Detailed information on the design of the trial is described elsewhere $(32,33)$. In summary, a randomized, double-blind, placebo-controlled exploratory phase II trial of the CD4 antibody cM-T412 was set up using a parallel groups design. As primary measure of treatment efficacy, the cumulative number of active lesions seen on monthly brain MRI, performed over 9 mo from the start of the treatment, after baseline correction, was used.

Patients. Analyses were carried out on 28 patients treated at the Department of Neurology, Free University Hospital (Amsterdam, The Netherlands), who formed a subgroup of patients from a larger multi-center study. After randomization 13 patients received placebo, and 15 received $\mathrm{CD} 4 \mathrm{mAb}$ treatment. Demographic and baseline characteristics are given in Table I. In contrast to what was seen in the total group of patients (32), patients in both treatment arms in this study were also comparable with respect to relapse rate in the year preceding inclusion (mean number \pm SD of clinical relapses in the previous year in the placebo vs. CD4 mAb group: $1.8 \pm 1.3$ vs. $1.5 \pm 1.1$, $P=0.49$ ), and with respect to the total number of active lesions at baseline (median number of active MR lesions at inclusion in the placebo vs. CD4 mAb group 0 vs. $1, P=0.15)$.

Reagents. mAbs directed against CD2 (CLB-T11.1/1, CLB-T11.1/2, and Hik27), CD28 (CLB-CD28/1), CD8 (FITC-labeled CLB-T8/4), and CD14 (FITC-labeled, CLB-mon/1) were generated at the Central Laboratory of The Netherlands Red Cross Blood Transfusion Service. PerCP-labeled CD3, CD4, and CD8 mAb, phycoerythrin (PE)labeled $\mathrm{CD} 4 \mathrm{mAb}$, and FITC-labeled CD3 $\mathrm{mAb}$ were purchased from Becton Dickinson Immunocytometry Systems (San Jose, CA). PElabeled CD45RA mAb (2H4-RD1) was obtained from Coulter Corp. (Miami, FL). FITC-labeled CD45R0 mAb (UCHL-1) and biotinylated $\mathrm{IgG1}$ control mAb were from Dako (Glostrup, Denmark), and FITC-labeled CD95 (Fas) mAb was purchased from Immunotech S.A. (Marseille, France). Streptavidin-PE was obtained from Molecular Probes (Leiden, The Netherlands). Biotinylated $\alpha$ IFN- $\gamma$

Table I. Demographic and Baseline Characteristics of Patients in Both Treatment Arms

\begin{tabular}{|c|c|c|c|}
\hline Variable & Placebo & Anti-CD4 & $P$ value \\
\hline \multicolumn{4}{|l|}{ Sex } \\
\hline Female & 9 & 6 & \\
\hline Male & 4 & 9 & 0.13 \\
\hline \multicolumn{4}{|l|}{ Disease type } \\
\hline Relapsing remitting & 8 & 7 & \\
\hline Secondary progressive & 5 & 8 & 0.44 \\
\hline Age $(y r)^{*}$ & $36.6 \pm 8.5$ & $33.7 \pm 6.8$ & 0.34 \\
\hline Disease duration $(\mathrm{yr})^{*}$ & $5.8 \pm 7.1$ & $3.2 \pm 3.0$ & 0.23 \\
\hline Number of clinical relapses previous year* & $1.8 \pm 1.3$ & $1.5 \pm 1.1$ & 0.49 \\
\hline EDSS $^{\ddagger}$ progression previous year $^{\S}$ & 1.0 & 1.5 & 0.33 \\
\hline EDSS at inclusion $\|$ & 5.5 & 5.5 & 0.85 \\
\hline $\mathrm{CD} 4$ cell numbers $/ \mathrm{mm}^{3}$ at inclusion* & $985 \pm 300$ & $810 \pm 237$ & 0.10 \\
\hline \multicolumn{4}{|l|}{ Presence of active MR lesions at inclusion } \\
\hline Present & 4 & 9 & \\
\hline Absent & 9 & 6 & 0.13 \\
\hline Number of active MR lesions at inclusion ${ }^{\S}$ & 0 & 1 & 0.15 \\
\hline
\end{tabular}

*Mean \pm SD; ${ }^{*}$ EDSS, Expanded Disability Status Scale; ${ }^{\S}$ median; "inclusion: month 0 .
mAb was purchased from Dr. P. van der Meide (Biomedical Primate Research Centre, Rÿswÿk, The Netherlands) and biotinylated $\alpha$ IL-4 $\mathrm{mAb}$ was kindly provided by Dr. T.C.T.M. van der Pouw-Kraan (Central Laboratory of The Netherlands Red Cross Blood Transfusion Service, Amsterdam, The Netherlands).

PMA (CMC Cancer Research, Katonah, NY) and ionomycin (Calbiochem, La Jolla, CA) were prepared as stock solutions in DMSO, stored at $-20^{\circ} \mathrm{C}$ and diluted properly before use.

Blood samples and cell separation. At each visit venous blood was collected in evacuated blood collection tubes (Vacutainer, Becton Dickinson, Meylan, France) containing sodium heparin (143 USP units). The samples were kept at room temperature and processed within $24 \mathrm{~h}$.

PBMC were isolated from heparinized blood by Ficoll-Isopaque density gradient centrifugation and were cryopreserved immediately. To minimize interassay variability, samples from all time points from individual patients were analyzed in one experiment. Viability of the cells was $>95 \%$, as indicated by trypan blue exclusion.

Standard culture technique. PBMC $\left(25 \times 10^{5}\right.$ cells $\left./ \mathrm{ml}\right)$ were cultured in IMDM, supplemented with $10 \%$ FCS, penicillin, streptomycin, and $\beta$-mercaptoethanol, in a final volume of $200 \mu \mathrm{l}$, and stimulated in triplicate cultures with a triplet of CD2 mAb (CLB-T11.1/1, CLB-T11.2/1, and Hik27; all $5 \mu \mathrm{g} / \mathrm{ml}$ ) in the presence of CD28 mAb CLB-CD28/1 (5 $\mu \mathrm{g} / \mathrm{ml})(34)$ in flat-bottom microtiter plates (Greiner, Langenthal, Switzerland). Cells cultured without stimuli served as negative controls.

The proliferative response $(\mathrm{cpm})$ was measured after $4 \mathrm{~d}$ of culture by means of incorporation of $\left[{ }^{3} \mathrm{H}\right]$ thymidine. $0.4 \mathrm{mCi} / \mathrm{well}$ of $\left[{ }^{3} \mathrm{H}\right]$ thymidine $(200 \mathrm{mCi} / \mathrm{mmol}$; Amersham, Buckinghamshire, United Kingdom) was added $24 \mathrm{~h}$ before harvesting.

Membrane phenotyping. PBMC were washed twice with PBS supplemented with $0.5 \%$ BSA and Na-azide $(5 \mu \mathrm{g} / \mathrm{ml})$. Immunofluorescence staining was performed by incubation of PBMC with saturating amounts of combinations of PerCP-, FITC-, and PE-labeled $\mathrm{mAb}$ in PBS/BSA. Stained cells were washed twice and $10^{4}$ viable lymphocytes were analyzed using a fluorescence activated cell sorter (FACS ${ }^{\circledR}$; Becton Dickinson, Sunnyvale, CA). Results are given as the absolute number of cells per $\mathrm{mm}^{3}$ blood. For the different $\mathrm{T}$ cell subsets these numbers were calculated using the total number of either $\mathrm{CD}^{3 \text { pos }}$ or $\mathrm{CD} 4^{\text {pos }} \mathrm{T}$ cells per $\mathrm{mm}^{3}$ blood.

Flow cytometric measurement of intracellular cytokine production. Measurement of cytokine production was performed as previously described $(35,36)$. Briefly, $0.5 \times 10^{6}$ cells $/ \mathrm{ml}$ were stimulated for $4 \mathrm{~h}$ with PMA $(1 \mathrm{ng} / \mathrm{ml})$ and ionomycin $(1 \mu \mathrm{M})$ in the presence of the protein-secretion inhibitor monensin $(1 \mu \mathrm{M})$. All subsequent steps were performed at $4^{\circ} \mathrm{C}$. After cell surface staining with CD3FITC, cells were washed twice with PBS and fixated with $\mathrm{PBS} / 4 \%$ paraformaldehyde $(5 \mathrm{~min})$. Fixation was followed by permeabilization with PBS/0.1\% saponin (Sigma) $/ 10 \%$ human pooled serum (10 $\mathrm{min}$ ). For all subsequent washing and incubation steps, $\mathrm{PBS} / 0.1 \%$ saponin $/ 0.5 \%$ BSA was used. Staining of the cytoplasm with biotinylated cytokine mAb (IL-4, IFN- $\gamma$; both $5 \mu \mathrm{g} / \mathrm{ml}$ ) was followed by incubation with streptavidin-PE (20 min). Analysis was performed as described for the measurement of membrane markers.

Statistical analysis. Differences between groups at baseline were analyzed using Student's $t$ test, Wilcoxon's test, or $\chi^{2}$ test. Repeated measurements MANOVA with age as a covariate was used to evaluate treatment effects. We considered $P$ values $<0.05$ to be statistically significant.

\section{Results}

CD4 mAb cM-T412 induces a long-lasting specific depletion of $C D 4^{\text {pos }} T$ cells. Treatment with the $\mathrm{CD} 4 \mathrm{mAb}$ resulted in a significant reduction in absolute numbers of circulating CD $3^{\text {pos }}$ T cells (Fig. $1 a, P=0.004)$. Within the total $\mathrm{CD}^{\text {pos }} \mathrm{T}$ cell population the $\mathrm{mAb}$ induced a significant and progressive decline 

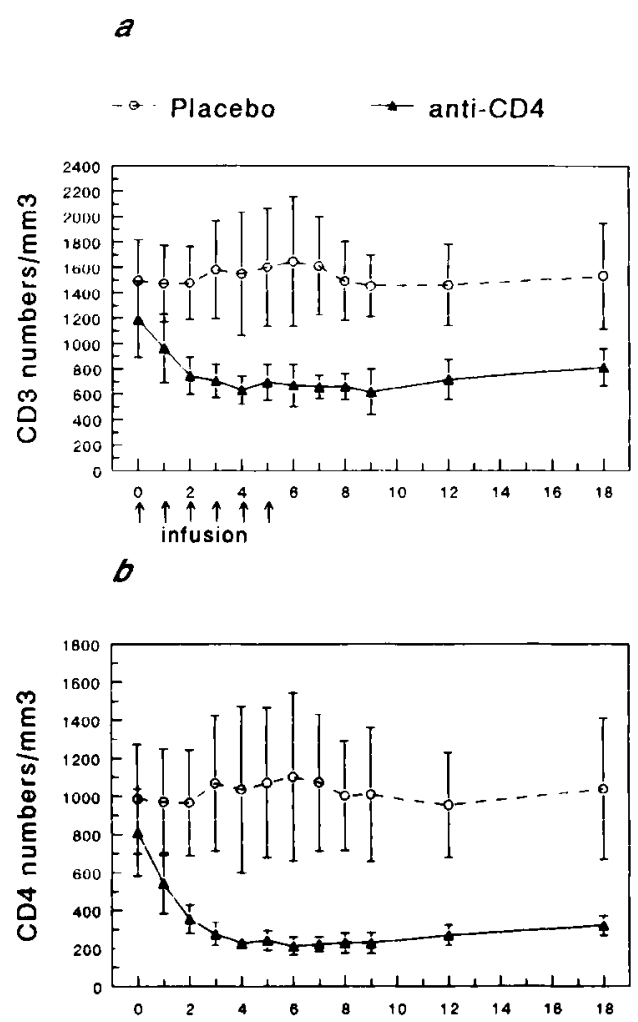

$c$

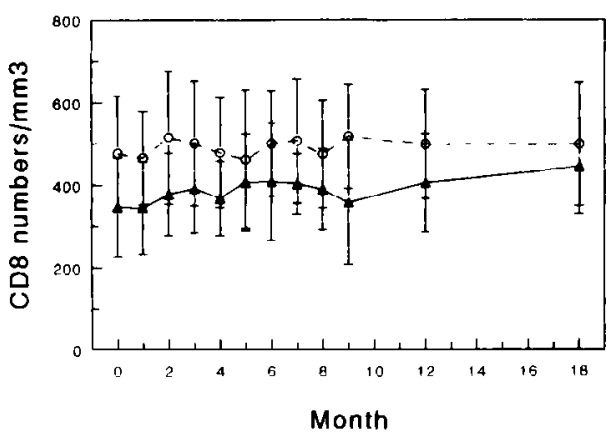

Figure 1. Depletion of CD4 $4^{\text {pos }} \mathrm{T}$ cells in peripheral blood of CD4 $\mathrm{mAb}$-treated MS patients. Mean numbers $( \pm \mathrm{SD})$ of T cells per $\mathrm{mm}^{3}$ blood are given for the placebo-treated group $(n=13$; open circles $)$ and the CD4 mAb-treated group ( $n=15$; closed triangles). ( $a)$ Mean $\mathrm{CD} 3$ numbers in the $\mathrm{CD} 4 \mathrm{mAb}$-treated group are decreased to $\sim 53 \%$ of the baseline level at month 4 , and to $68 \%$ at month 18 . The difference with the placebo-treated group is statistically significant. (b) A significant decline in $\mathrm{CD} 4^{\text {pos }} \mathrm{T}$ cell numbers in the $\mathrm{CD} 4 \mathrm{mAb}-$ treated group in comparison with the placebo-treated group. At month 4 mean $\mathrm{CD}^{4{ }^{\text {pos }}} \mathrm{T}$ cell numbers are decreased to $\sim 30 \%$ of the baseline level. Strikingly, at month 18 , long after termination of treatment, mean $\mathrm{CD} 4{ }^{\text {pos }} \mathrm{T}$ cell numbers are still reduced to $\sim 39 \%$ of the pretreatment level. (c) CD8 ${ }^{\text {pos }} \mathrm{T}$ cell numbers are not affected by the treatment.

in $\mathrm{CD}^{\text {pos }} \mathrm{T}$ cell numbers which was most prominent until month 4 (to $30 \%$ of the pretreatment level, Fig. $1 \mathrm{~b}, \mathrm{P}<$ 0.001 ), at which time point CD4 mAb treatment for the majority of the patients was interrupted or discontinued (32). A remarkable finding was that, long after termination of treatment,
CD4 $4^{\text {pos }} \mathrm{T}$ cell numbers remained low. 18 mo after cessation of treatment $\mathrm{CD} 4^{\text {pos }} \mathrm{T}$ cell numbers were still reduced to $\sim 39 \%$ of the pretreatment level. CD8 numbers showed a slight increase in the CD4 mAb-treated group (to $128 \%$ of the pretreatment level at month 18 , Fig. $1 c$ ), but this was not significantly different from the placebo-treated group.

Because monocytes also express the CD4 antigen, albeit at lower levels than $\mathrm{T}$ cells, we investigated whether these cells were affected by treatment with the CD4 antibody. However, at none of the time points were differences seen between the CD4 mAb-treated group and the placebo-treated group in the number of monocytes per $\mathrm{mm}^{3}$ blood (data not shown).

$C D 4 m A b$ treatment does not affect $T$ cell reactivity in a quantitative fashion. In HIV-1 infection numeric depletion of the $\mathrm{CD} 4^{\text {pos }} \mathrm{T}$ cell compartment coincides with a diminished ability of $\mathrm{T}$ cells to proliferate in vitro $(37,38)$. To investigate whether treatment with CD4 mAb had a similar effect on $\mathrm{T}$ cell reactivity, $\mathrm{T}$ cell proliferation in vitro was analyzed. These assays were performed in standard cultures, using isolated PBMC, under optimal stimulation conditions, in order to measure the response per standard amount of PBMC (39). There were no differences in proliferative capacity of circulating $\mathrm{T}$ cells between the two groups as a result of treatment (Fig. 2). Therefore, we conclude that CD4 mAb treatment does not affect reactivity of the remaining circulating $\mathrm{T}$ cells in a quantitative way.

Distinct sensitivities of unprimed and primed CD4 $4^{\text {pos }} T$ cells for depleting $C D 4 m A b$. Next, to more precisely define the target cells of the CD4 mAb we investigated if different subsets of $\mathrm{CD} 4^{\text {pos }} \mathrm{T}$ cells are equally affected by CD4 mAb treatment. Triple-color immunofluorescence analysis revealed that in placebo-treated patients, numbers of unprimed $\mathrm{CD} 4^{\text {pos }}$ $\mathrm{CD} 45 \mathrm{RA}^{\text {pos }} / \mathrm{R} 0^{\text {neg }}$ and primed $\mathrm{CD} 4{ }^{\text {pos }} \mathrm{CD} 45 \mathrm{RA}^{\text {neg }} / \mathrm{R} 0^{\text {pos }} \mathrm{T}$ cells (40) remained constant during the study period (Fig. $3 a$ ). At baseline the CD4 $\mathrm{mAb}$-treated group had relatively more unprimed than primed circulating CD $4{ }^{\text {pos }} \mathrm{T}$ cells (Fig. $3 b$; NS).

\section{Standard culture}

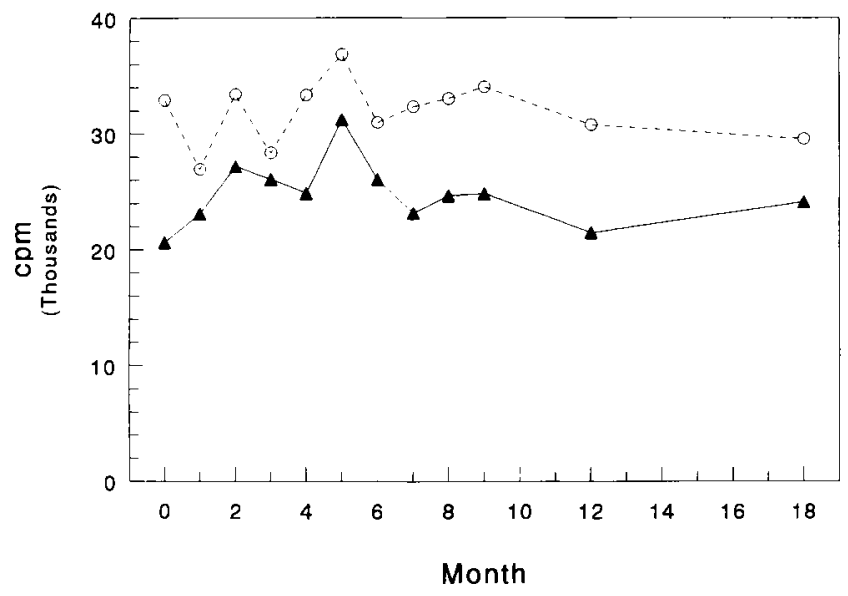

Figure 2. Mean proliferative capacity of circulating T cells in standard cultures (per standard amount of PBMC) is not decreased in the $\mathrm{CD} 4 \mathrm{mAb}$-treated group (closed triangles) and is not different from that of the placebo-treated group (open circles). T cells were stimulated with a triplet of $\mathrm{CD} 2 \mathrm{mAb}$ in combination with CD28 mAb. 

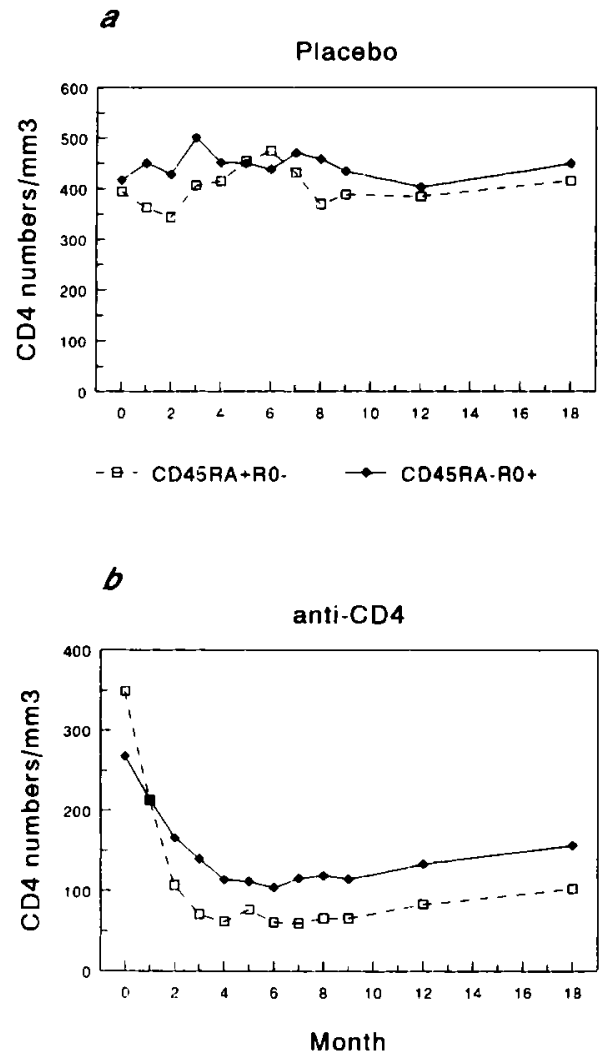
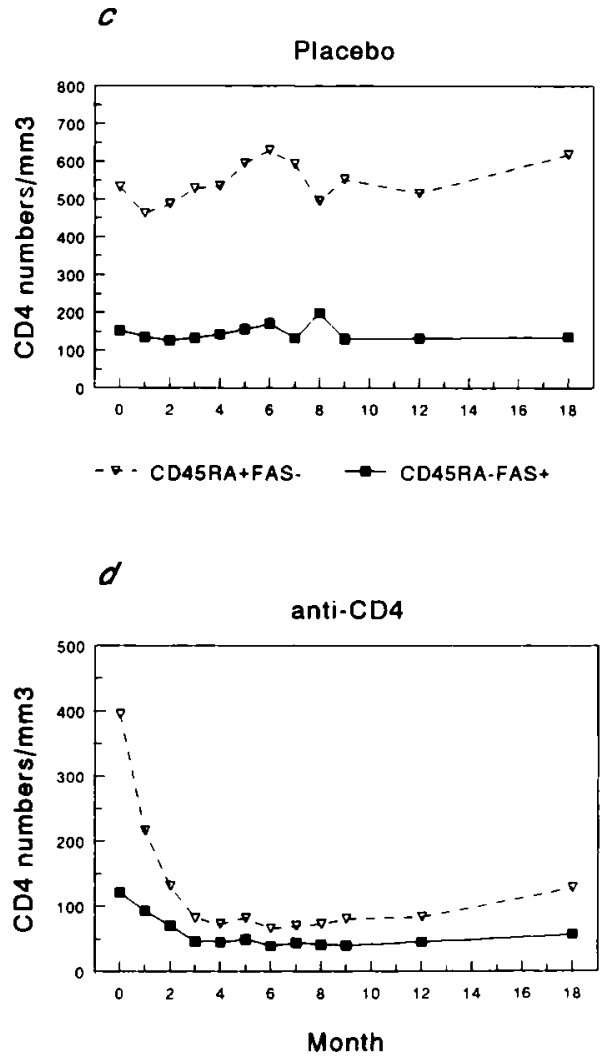

Figure 3. Preferential deletion of unprimed CD4 ${ }^{\text {pos }} \mathrm{T}$ cells while primed $\mathrm{CD} 4^{\text {pos }} \mathrm{T}$ cells are relatively resistant. Numbers of both $\mathrm{CD} 4^{\text {pos }} \mathrm{CD} 45 \mathrm{RA}^{\text {pos }} / \mathrm{R} 0^{\text {neg }}$ (open squares) and CD4 ${ }^{\text {pos }} C D 45 \mathrm{RA}^{\text {neg }} / \mathrm{R} 0^{\text {pos }}$ (closed diamonds) $\mathrm{T}$ cells remain relatively stable in the placebo-treated group $(a)$, while in the $\mathrm{CD} 4 \mathrm{mAb}$-treated group $(b)$ $\mathrm{CD}^{\text {pos }}{ }^{\mathrm{CD}} 45 \mathrm{RA}^{\mathrm{pos}} / \mathrm{R} 0^{\text {neg }}$ are more depleted than CD4 ${ }^{\text {pos }}$ CD $45 \mathrm{RA}^{\text {neg }} / \mathrm{R} 0^{\text {pos }} \mathrm{T}$ cells. Differences between groups were significant for both parameters $\left(\mathrm{CD} 4{ }^{\text {pos }} \mathrm{CD} 45 \mathrm{RA}^{\mathrm{pos} /}\right.$ R0 ${ }^{\text {neg }}$ T cells: $P<0.001$, CD4 ${ }^{\text {pos }}$ CD $45 R^{\text {neg }} / \mathrm{R}^{\text {pos }} \mathrm{T}$ cells: $P=0.002)$. Within the CD4 ${ }^{\text {pos }}$ CD45RA ${ }^{\text {pos }}$ subset no changes were found in both Fas $^{\text {neg }}$ (open triangles) and Fas ${ }^{\text {pos }}$ (closed squares) T cells in the placebo-treated group $(c)$. In the $\mathrm{CD} 4 \mathrm{mAb}$-treated group a far more vigorous depletion of CD4 ${ }^{\text {pos }}$ CD45RA ${ }^{\text {pos }}$ Fas $^{\text {neg }}$ T cells occurs as compared with the CD4 ${ }^{\text {pos }} \mathrm{CD} 45 \mathrm{RA}^{\text {pos }} \mathrm{Fas}^{\text {pos }} \mathrm{T}$ cells (d). Differences between groups were significant for CD4 ${ }^{\text {pos }}$ CD45RA ${ }^{\text {pos }}$ Fas $^{\text {neg }}$ T cells $(P=0.002)$, but not for CD4 ${ }^{\text {pos }}$ CD45RA ${ }^{\text {pos }} \mathrm{Fas}^{\text {pos }} \mathrm{T}$ cells.
Remarkably, although absolute numbers of both subsets declined as a result of CD4 mAb treatment, the decline was much more pronounced in the $\mathrm{CD} 4{ }^{\text {pos }} \mathrm{CD} 45 \mathrm{RA}^{\text {pos }} / \mathrm{R} 0^{\text {neg }}$ subset (at month 4 to $18 \%$ of the pretreatment level, $P<0.001$ ) as compared with the $\mathrm{CD} 4{ }^{\text {pos }} \mathrm{CD} 45 \mathrm{RA}{ }^{\text {neg }} / \mathrm{R}^{\text {pos }}$ subset (at month 4 to $59 \%$ of the pretreatment level, $P=0.002$ ). As a consequence, the ratio CD45RA ${ }^{\text {pos}} / C D 45 \mathrm{RA}^{\text {neg }} \mathrm{CD} 4{ }^{\text {pos }} \mathrm{T}$ cells was reversed, which remained so until the end of the study period. After termination of treatment, numbers of both CD45RA ${ }^{\text {pos }}$ and CD45RA ${ }^{\text {neg }}$ CD4 ${ }^{\text {pos }} \mathrm{T}$ cells increased in parallel.

When unprimed, naive CD4 ${ }^{\text {pos }} \mathrm{T}$ cells are activated, the Fas antigen is rapidly upregulated (41). Consequently, a further subdivision can be made within the $C D 4^{\text {pos }} C D 45 R A^{\text {pos }} / \mathrm{R} 0^{\text {neg }}$ subset based on Fas expression. Fas ${ }^{\text {neg }}$ cells may be regarded as truly naive $\mathrm{CD} 4^{\text {pos }} \mathrm{T}$ cells, whereas Fas-expressing $\mathrm{T}$ cells are likely to have been recently activated in vivo. This type of analysis showed that CD4 mAb treatment resulted in a sharp decline in the number of CD ${ }^{\text {pos }} \mathrm{CD} 45 \mathrm{RA}^{\text {pos }} \mathrm{Fas}^{\text {neg }} \mathrm{T}$ cells (Fig. $3 c, P=0.002)$, while the decline in the number of $\mathrm{CD} 4^{\text {pos }}$ CD45RA ${ }^{\text {pos }}$ Fas $^{\text {pos }} \mathrm{T}$ cells was much less pronounced (Fig. 3 $d, \mathrm{NS})$.

IFN- $\gamma$-producing $T$ cells are not affected by CD4 mAb treatment. Secretion of $\mathrm{TH} 1$ and $\mathrm{TH} 2$ cytokines, a qualitative feature of $\mathrm{T}$ cell function, is largely restricted to the primed CD4 $4^{\text {pos }} \mathrm{T}$ cell subset $(36,42)$. Since, as we have already mentioned, autoimmune diseases are believed to be dependent on the activation of IFN- $\gamma$-producing TH1-type cells, we investigated, taking into account the above documented relatively low sensitivity of primed T cells to therapy, whether $\mathrm{CD} 4 \mathrm{mAb}$ treatment would differentially affect TH1- and TH2-type cells. For this we measured absolute numbers of IFN- $\gamma-$ and IL-4producing $\mathrm{T}$ cells using flow cytometry $(35,36)$. IFN- $\gamma-$ and IL-4-producing T cells remained constant in the placebo group over time (Fig. 4, $a$ and $b$ ). Numbers of IL-4-producing CD $3^{\text {pos }}$ $\mathrm{T}$ cells showed an almost $50 \%$ decline in the CD4 mAbtreated group (Fig. $4 b$, NS), which is comparable with the decline seen in the CD4 ${ }^{\text {pos }} \mathrm{CD} 45 \mathrm{RA}^{\mathrm{neg}} / \mathrm{R} 0^{\text {pos }} \mathrm{T}$ cells. Remarkably, however, numbers of IFN- $\gamma$-producing $\mathrm{CD}^{\text {pos }} \mathrm{T}$ cells remained relatively stable over time in the CD4 mAb-treated group (Fig. $4 a$, NS). As a result, treatment with $\mathrm{CD} 4 \mathrm{mAb}$ resulted in a significant increase in the TH1/TH2 ratio (Fig. $4 c$, $P=0.035)$.

\section{Discussion}

Analysis of the T cell compartment in MS patients treated with the chimeric monoclonal antibody cM-T412 shows that the CD $4 \mathrm{mAb}$ induces a long-lasting selective depletion of the circulating CD4pos compartment (Fig. 1 and reference 32). Repopulation studies in mice and in patients undergoing intensive chemotherapy $(43,44)$ have shown that $C D 4^{\text {pos }} \mathrm{T}$ cell repopulation is inversely correlated with age, and that rapid reconstitution of this pool requires residual thymic function. Because even young adults already have relative deficiencies in this thymus-dependent pathway, it is therefore not surpris- 


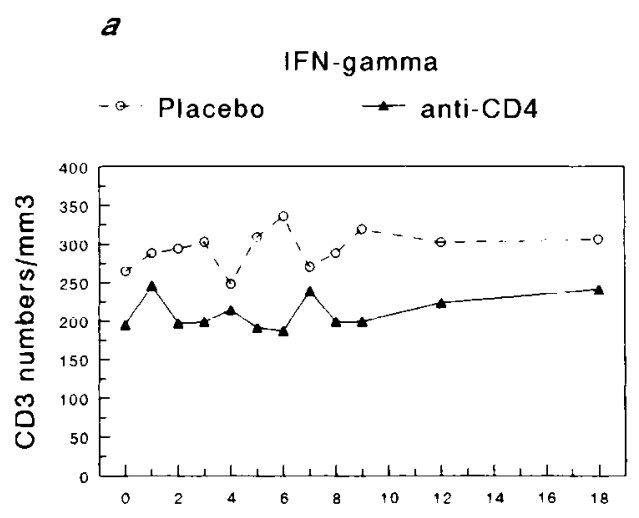

$b$

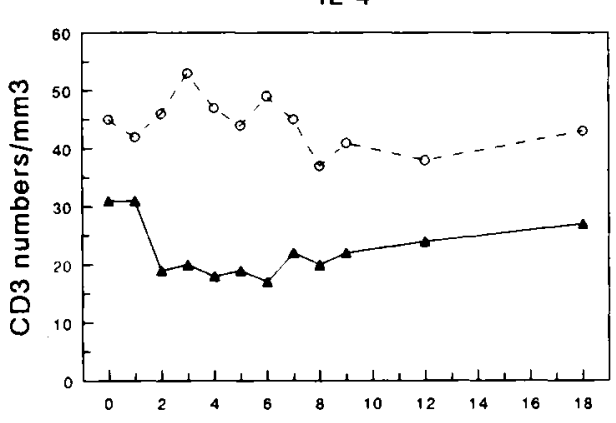

$c$

\section{TH1/TH2}

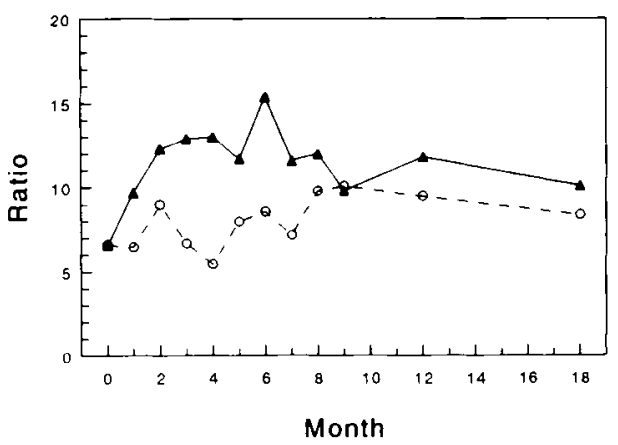

Figure 4. $\mathrm{CD}^{\text {pos }} \mathrm{T}$ cells producing the TH1-type cytokine $\mathrm{IFN}-\gamma(a)$ are not affected by CD4 $\mathrm{mAb}$ treatment, while there is a decline in the number of $\mathrm{CD}^{\text {pos }} \mathrm{T}$ cells producing the $\mathrm{TH} 2$-type cytokine IL-4 (b). Results are expressed as the mean number of $\mathrm{CD} 3^{\text {pos }} \mathrm{T}$ cells producing either of the two cytokines. Open circles represent the placebo-treated group and closed triangles represent the CD4 mAbtreated group. For both parameters the difference between the two groups is not significant. The ratio of TH1/TH2-type cells is increased after CD4 mAb treatment $(P=0.035)$.

ing to find that the $\mathrm{CD} 4^{\text {pos }} \mathrm{T}$ cell depletion lasted so long in our anti-CD4-treated group. Furthermore, the fact that reconstitution of CD4 ${ }^{\text {pos }} \mathrm{CD} 45 \mathrm{R} 0^{\text {pos }} \mathrm{T}$ cells occurs in parallel with that of the $\mathrm{CD} 4{ }^{\text {pos }} \mathrm{CD} 45 \mathrm{RA}^{\mathrm{pos}} / \mathrm{R} 0^{\text {neg }} \mathrm{T}$ cells is in concordance with the notion that $C D 4^{\text {pos }} \mathrm{T}$ cell recovery mainly consist of the appearance of $\mathrm{CD} 4{ }^{\text {pos }} \mathrm{CD} 45 \mathrm{RA} \mathrm{A}^{\text {pos }} / \mathrm{R} 0^{\text {neg }} \mathrm{T}$ cells in the circulation (44), and favors the hypothesis that the majority of the circulating $\mathrm{CD} 4{ }^{\mathrm{pos}} \mathrm{CD} 45 \mathrm{R} 0^{\text {pos }} \mathrm{T}$ cells are generated by priming of
$\mathrm{CD} 4{ }^{\mathrm{pos}} \mathrm{CD} 45 \mathrm{RA}^{\mathrm{pos}} / \mathrm{R} 0^{\text {neg }} \mathrm{T}$ cells, rather than from the division of CD4 ${ }^{\text {pos }} \mathrm{CD} 45 \mathrm{R} 0^{\text {pos }} \mathrm{T}$ cells.

The blind homeostasis model predicts that in a given individual a constant number of circulating CD $3^{\text {pos }}$ lymphocytes is maintained irrespective of CD4pos or CD8pos phenotype (45, 46) and implies that in case of $C D 4^{\text {pos }} \mathrm{T}$ cell loss, such as in HIV-1 infection, both $\mathrm{CD} 4^{\text {pos }}$ and CD8 ${ }^{\text {pos }} \mathrm{T}$ cells will be produced in increasing amounts until the $C D 3^{\text {pos }} \mathrm{T}$ cell steady state is restored. Because of the effect of HIV-1 on CD $4^{\text {pos }}$, but not on CD8 $8^{\text {pos }} \mathrm{T}$ cells, this would then result in $\mathrm{CD} 8^{\text {pos }} \mathrm{T}$ cell lymphocytosis in the circulation. However, the data from the CD4 mAb-treated patients in this study show that although the loss in $\mathrm{CD} 4^{\text {pos }} \mathrm{T}$ cell numbers is pronounced, this is not compensated by an increase in $C D 8^{\text {pos }} \mathrm{T}$ cell numbers, not even in the long term. Consequently, numbers of $\mathrm{CD}^{\text {pos }} \mathrm{T}$ cells are significantly reduced after treatment. It is likely that in HIV-1 infection other factors, such as continuous antigenic pressure and bystander activation through regulatory cytokines, contribute to the CD8 ${ }^{\text {pos }}$ lymphocytosis (47). Based on the data presented here we feel that the blind homeostasis model needs reconsideration.

Our data demonstrate a differential sensitivity of unprimed CD45RA ${ }^{\text {pos }}$ versus primed CD45RA ${ }^{\text {neg }} C D 4{ }^{\text {pos }} \mathrm{T}$ cells for depletion by the cM-T412 mAb. The fact that within the CD4 ${ }^{\text {pos }}$ CD45RA ${ }^{\text {pos }}$ subpopulation Fas ${ }^{\text {neg }} \mathrm{T}$ cells are more sensitive to treatment than Fas ${ }^{\text {pos }} \mathrm{T}$ cells shows that the depletion is not simply related to expression of CD45RA, but that actually $\mathrm{CD} 4^{\text {pos }} \mathrm{T}$ cells which have not yet been activated in vivo are most sensitive to the depleting effect of the mAb. Also within the $C D 4{ }^{\text {pos }} C D 45 \mathrm{RA}^{\text {neg }} \mathrm{T}$ cell subset, a distinction in sensitivity for the CD4 mAb could be made on the basis of qualitative features of $\mathrm{T}$ cell function. While numbers of circulating T cells producing IFN- $\gamma$ were not affected, IL-4-producing $\mathrm{T}$ cells were selectively depleted. Therefore, treatment results in a relative increase in $\mathrm{R} 0^{\text {pos }} \mathrm{TH} 1$ cells in the peripheral blood.

The mechanism of $\mathrm{CD} 4{ }^{\text {pos }} \mathrm{T}$ cell depletion after treatment with $\mathrm{CD} 4 \mathrm{mAb}$ is unclear and consequently the basis for the distinct sensitivities of $\mathrm{T}$ cell subpopulations to the CD4 $\mathrm{mAb}$ is hard to define. A role for Fas in the CD4 mAb-induced deletion process has been suggested by the observation that mice lacking a functional Fas receptor do not show a decrease of CD4 ${ }^{\text {pos }} \mathrm{T}$ cells after treatment with depleting CD4 mAb (48). In agreement with this, engagement of the CD4 molecule by CD4 mAb independent of the $\mathrm{T}$ cell antigen receptor leads to a small but rapid increase in cell surface Fas expression and Fas antigen-dependent apoptosis of $\mathrm{T}$ cells $(48,49)$. Interestingly, when $\mathrm{T}$ cells are activated by $\mathrm{CD} 3$ antibodies, either in vitro or in vivo, they become resistant to $\mathrm{CD} 4 \mathrm{mAb}-$ mediated deletion $(50,51)$. At first glance it seems paradoxical that activation of $\mathrm{T}$ cells with $\mathrm{CD} 3 \mathrm{mAb}$, which induces membrane expression of Fas, renders them insensitive to a deletion process that involves Fas-mediated apoptosis. However, it should be noted that when unprimed $\mathrm{T}$ cells are activated with $\mathrm{CD} 3 \mathrm{mAb}$, they are induced to express Fas but remain insensitive to Fasmediated cell death (52). These observations suggest that $\mathrm{T}$ cells can be rescued from CD4 mAb-induced Fas-mediated deletion by signals, generated via TCR/CD3, which normally protect antigen-stimulated $\mathrm{T}$ cells from apoptosis. If this notion is valid it could explain the finding that murine and human $\mathrm{T}$ cells with membrane characteristics of activation (including Fas expression) are relatively resistant to depleting CD4 $\mathrm{mAb}$ $(43,53)$. 
Treatment with the cM-T412 mAb did not have any effect on disease activity in our group of MS patients as measured by the number of active lesions on monthly gadolinium-enhanced MRI over 9 mo (32). Although phase I clinical trials seemed to be promising $(24,27-29)$ also in other chronic human autoimmune diseases, little or no clinical effect of treatment with CD4 antibodies could be demonstrated in placebo-controlled phase II clinical trials $(31,32,54)$. The absence of clinical benefit differs markedly from the encouraging results that have been obtained in experimental model systems for autoimmunity. An important point in the explanation for this discrepancy seems to be the timing of the administration of the CD4 antibody in relation to the stage of the disease process. In most of the animal models where this kind of treatment is successful, the antibody was given during the period of disease induction $(13,19,55)$. In these models, development of disease is probably dependent on the recruitment of naive $\mathrm{T}$ cells upon antigenic stimulation. Therefore, it is conceivable that treatment is effective, considering the fact that naive cells are preferentially deleted by the antibody. In agreement with the recent observations in various patient groups, in animal models administration of $\mathrm{CD} 4 \mathrm{mAb}$ has been unsuccessful in the treatment of already established disease $(18,56-58)$. Apparently, ongoing immune responses in vivo are not effectively influenced by the administration of depleting CD4 mAb. In agreement with this, our results show that depleting CD4 mAb does not affect the cell type most strongly implicated in the pathogenesis of human autoimmune disease, i.e., IFN- $\gamma$-producing TH1-type cells. Future therapies for chronic inflammatory $\mathrm{T}$ cell-mediated diseases have to take into account that intervention in ongoing immune responses must be directed at the primed TH1 T cell subset.

\section{Acknowledgments}

The authors wish to thank Drs. S.M.A. Lens, W.L. v.d. Graaf, R.Q. Hintzen, M.R. Klein, P.T.A. Schellekens, and F. Miedema for critically reviewing the manuscript, and people working in the lab of Marijke Roos (Central Laboratory of The Netherlands Red Cross Blood Transfusion Service, Amsterdam, The Netherlands) and Guus Westra from the lab of Peter Huygens (Haematology, Free University Hospital, Amsterdam, The Netherlands) for technical assistance.

This study was supported by grant 94-192 from the Dutch Society for Support of Research on Multiple Sclerosis.

\section{References}

1. Brown, J.H., T.S. Jardetzky, J.C. Gorga, L.J. Stern, R.G. Urban, J.L. Strominger, and D.C. Wiley. 1993. Three-dimensional structure of the human class II histocompatibility antigen HLA-DR1. Nature (Lond.). 364:33-39.

2. Janeway, C.A.J., S. Carding, B. Jones, J. Murray, P. Portoles, R. Rasmussen, J. Rojo, K. Saizawa, J. West, and K. Bottomly. 1988. CD4+ T cells: specificity and function. Immunol. Rev. 101:39-80.

3. Banchereau, J., F. Bazan, D. Blanchard, F. Briere, J.P. Galizzi, C. Van Kooten, Y.J. Liu, F. Rousset, and S. Saeland. 1994. The CD40 antigen and its ligand. Annu. Rev. Immunol. 12:881-922.

4. Bottomly, K. 1988. A functional dichotomy in CD4+ T lymphocytes. Immunol. Today. 9:268-274.

5. Mosmann, T.R., and R.L. Coffman. 1989. TH1 and TH2 cells: different patterns of lymphokine secretion lead to different functional properties. Anпи. Rev. Immunol. 7:145-173.

6. Romagnani, S. 1991. Human TH1 and TH2 subsets: doubt no more. Immunol. Today. 12:256-257.

7. Seder, R.A., and W.E. Paul. 1994. Acquisition of lymphokine-producing phenotype by CD4+ T cells. Annu. Rev. Immunol. 12:635-673.

8. Druet, P., R. Sheela, and L. Pelletier. 1995. Th1 and Th2 cells in autoimmunity. Clin. Exp. Immunol. 101(Suppl. 1):9-12.
9. Charlton, B., and K.J. Lafferty. 1995. The Th1/Th2 balance in autoimmunity. Curr. Opin. Immunol. 7:793-798.

10. Zamvil, S.S., and L. Steinman. 1990. The T lymphocyte in experimental allergic encephalomyelitis. Annu. Rev. Immunol. 8:579-621.

11. Acha Orbea, H., L. Steinman, and H.O. McDevitt. 1989. T cell receptors in murine autoimmune diseases. Annu. Rev. Immunol. 7:371-405.

12. Zamvil, S.S., D.J. Mitchell, M.B. Powell, K. Sakai, J.B. Rothbard, and L. Steinman. 1988. Multiple discrete encephalitogenic epitopes of the autoantigen myelin basic protein include a determinant for I-E class II-restricted T cells. J. Exp. Med. 168:1181-1186.

13. Brostoff, S.W., and D.W. Mason. 1984. Experimental allergic encephalomyelitis: successful treatment in vivo with a monoclonal antibody that recognizes T helper cells. J. Immunol. 133:1938-1942.

14. Waldor, M.K., S. Sriram, R. Hardy, L.A. Herzenberg, L. Lanier, M. Lim, and L. Steinman. 1985. Reversal of experimental allergic encephalomyelitis with monoclonal antibody to a T-cell subset marker. Science (Wash. DC). 227:415-417.

15. van Lambalgen, R., and M. Jonker. 1987. Experimental allergic encephalomyelitis in rhesus monkeys. II. Treatment of EAE with anti-T lymphocyte subset monoclonal antibodies. Clin. Exp. Immunol. 68:305-312.

16. van Lambalgen, R., and M. Jonker. 1987. Experimental allergic encephalomyelitis in rhesus monkeys. I. Immunological parameters in EAE resistant and susceptible rhesus monkeys. Clin. Exp. Immunol. 68:100-107.

17. Pelegri, C., M.P. Morante, C. Castellote, A. Franch, and M. Castell. 1996. Treatment with an anti-CD4 monoclonal antibody strongly ameliorates established rat adjuvant arthritis. Clin. Exp. Immunol. 103:273-278.

18. Williams, R.O., and A. Whyte. 1996. Anti-CD4 monoclonal antibodies suppress murine collagen-induced arthritis only at the time of primary immunization. Cell. Immunol. 170:291-295.

19. Reynolds, J., and C.D. Pusey. 1994. In vivo treatment with a monoclonal antibody to $\mathrm{T}$ helper cells in experimental autoimmune glomerulonephritis in the BN rat. Clin. Exp. Immunol. 95:122-127.

20. Tomer, Y., M. Blank, and Y. Shoenfeld. 1994. Suppression of experimental antiphospholipid syndrome and systemic lupus erythematosus in mice by anti-CD4 monoclonal antibodies. Arthritis Rheum. 37:1236-1244.

21. Kumar, V., and E.E. Sercarz. 1991. Regulation of autoimmunity. Curr. Opin. Immunol. 3:888-895.

22. Hutchings, P., N. Parish, L. O'Reilly, K. Dawe, I.M. Roitt, and A. Cooke. 1993. The regulation of autoimmunity through CD4+ T cells. Autoimmunity. 15(Suppl.):21-23.

23. Racadot, E., J. Wijdenes, and D. Wendling. 1992. Immunological follow-up of 17 patients with rheumatoid arthritis treated in vivo with an anti-T CD4+ monoclonal antibody (B-F5). Clin. Exp. Rheumatol. 10:365-374.

24. Moreland, L.W., R.P. Bucy, A. Tilden, P.W. Pratt, A.F. LoBuglio, M. Khazaeli, M.P. Everson, P. Daddona, J. Ghrayeb, C. Kilgarriff, et al. 1993. Use of a chimeric monoclonal anti-CD4 antibody in patients with refractory rheumatoid arthritis. Arthritis Rheum. 36:307-318.

25. van der Lubbe, P.A., C. Reiter, F.C. Breedveld, K. Kruger, M. Schattenkirchner, M.E. Sanders, and G. Riethmüller. 1993. Chimeric monoclonal antibody cM-T412 as a therapeutic approach to rheumatoid arthritis. Arthritis Rheum. 10:1375-1379.

26. Hiepe, F., H.D. Volk, E. Apostoloff, R. von Baehr, and F. Emmrich. 1991. Treatment of severe systemic lupus erythematosus with anti-CD4 monoclonal antibody [letter]. Lancet. 338:1529-1530.

26a. Stronkhorst, A., S. Radema, S.-L. Yong, H. Bijl, I.J.M. ten Berge, G.N.J. Tytgat, and S.J.H. van Deventer. 1997. CD4 antibody treatment in patients with active Crohn's disease. Gut. In press.

27. Racadot, E., L. Rumbach, M. Bataillard, J. Galmiche, J.L. Henlin, M. Truttmann, P. Herve, and J. Wijdenes. 1993. Treatment of multiple sclerosis with anti-CD4 monoclonal antibody. A preliminary report on B-F5 in 21 patients. J. Autoimmun. 6:771-786.

28. Lindsey, J.W., S. Hodgkinson, R. Mehta, R.C. Siegel, D.J. Mitchell, M. Lim, C. Piercy, T. Tram, L. Dorfman, D. Enzmann, et al. 1994. Phase 1 clinical trial of chimeric monoclonal anti-CD4 antibody in multiple sclerosis. Neurology. 44:413-419.

29. Lindsey, J.W., S. Hodgkinson, R. Mehta, D. Mitchell, D. Enzmann, and L. Steinman. 1994. Repeated treatment with chimeric anti-CD4 antibody in multiple sclerosis. Ann. Neurol. 36:183-189.

30. Choy, E.H., I.C. Chikanza, G.H. Kingsley, V. Corrigall, and G.S. Panayi. 1992. Treatment of rheumatoid arthritis with single dose or weekly pulses of chimaeric anti-CD4 monoclonal antibody. Scand. J. Immunol. 36:291298.

31. Moreland, L.W., P.W. Pratt, M.D. Mayes, A. Postlethwaite, M.H. Weisman, T. Schnitzer, R. Lightfoot, L. Calabrese, D.J. Zelinger, J.N. Woody, et al. 1995. Double-blind, placebo-controlled multicenter trial using chimeric monoclonal anti-CD4 antibody, cM-T412, in rheumatoid arthritis patients receiving concomitant methotrexate. Arthritis Rheum. 38:1581-1588.

32. Van Oosten, B.W., M. Lai, S. Hodgkinson, F. Barkhof, D.H. Miller, I.F. Moseley, A.J. Thompson, P. Rudge, A. McDougall, J.G. McLeod, et al. 1997. Treatment of multiple sclerosis with the monoclonal anti-CD4 antibody cM412; results of a randomized, double-blind, placebo-controlled, MR-monitored phase II trial. Neurology. In press. 
33. Van Oosten, B.W., M. Lai, F. Barkhof, D.H. Miller, I.F. Moseley, A.J. Thompson, S. Hodgkinson, and C.H. Polman. 1996. A phase II trial of anti-CD4 antibodies in the treatment of multiple sclerosis. Multiple Sclerosis. 1:339-342.

34. Van Kemenade, F.J., E. Tellegen, M.M. Maurice, A.C. Lankester, T.W. Kuijpers, M. Brouwer, R. De Jong, F. Miedema, and R.A. van Lier. 1994. Simultaneous regulation of $\mathrm{CD} 2$ adhesion and signaling functions by a novel CD2 monoclonal antibody. J. Immunol. 152:4425-4432.

35. Jung, T., U. Schauer, C. Heusser, C. Neuman, and C. Rieger. 1993. Detection of intracellular cytokines by flow cytometry. J. Immunol. Methods. 159: 197-207.

36. Hamann, D., P.A. Baars, B. Hooibrink, and R.A.W. Van Lier. 1996. Heterogeneity of the human CD4+ T-cell population: two distinct CD4+ T-cell subsets characterized by coexpression of CD45RA and CD45R0 isoforms. Blood. 9:3513-3521.

37. Schellekens, P.T., M.T. Roos, F. De Wolf, J.M. Lange, and F. Miedema. 1990. Low T-cell responsiveness to activation via CD3/TCR is a prognostic marker for acquired immunodeficiency syndrome (AIDS) in human immunodeficiency virus-1 (HIV-1)-infected men. J. Clin. Immunol. 10:121-127.

38. Gruters, R.A., F.G. Terpstra, R.E. De Goede, J.W. Mulder, F. De Wolf, P.T. Schellekens, R.A. van Lier, M. Tersmette, and F. Miedema. 1991. Immunological and virological markers in individuals progressing from seroconversion to AIDS. AIDS. 5:837-844.

39. Rep, M.H.G., R.Q. Hintzen, C.H. Polman, and R.A. van Lier. 1994. Functional defects in peripheral blood T cells of multiple sclerosis patients. Diminished in vitro responsiveness in accessory cell dependent activation systems. J. Neuroimmunol. 52:139-146.

40. Sanders, M.E., M.W. Makgoba, and S. Shaw. 1988. Human naive and memory T cells: reinterpretation of helper-inducer and suppressor-inducer subsets. Immunol. Today. 9:195-199.

41. Hintzen, R.Q., R. De Jong, S.M.A. Lens, M. Brouwer, P. Baars, and R.A.W. Van Lier. 1993. Regulation of CD27 expression on subsets of mature T-lymphocytes. J. Immunol. 151:2426-2435

42. Picker, L.J., M.K. Singh, Z. Zdraveski, J.R. Treer, S.L. Waldrop, P.R. Bergstresser, and V.C. Maino. 1995. Direct demonstration of cytokine synthesis heterogeneity among human memory/effector T cells by flow cytometry. Blood. $86: 1408-1419$.

43. Rice, J.C., and R.P. Bucy. 1995. Differences in the degree of depletion, rate of recovery, and the preferential elimination of naive $\mathrm{CD} 4+\mathrm{T}$ cells by anti-CD4 monoclonal antibody (GK1.5) in young and aged mice. J. Immunol. 154:6644-6654.

44. Mackall, C.L., T.A. Fleisher, M.R. Brown, M.P. Andrich, C.C. Chen, I.M. Feuerstein, M.E. Horowitz, I.T. Magrath, A.T. Shad, S.M. Steinberg, et al. 1995. Age, thymopoiesis, and CD4+ T-lymphocyte regeneration after intensive chemotherapy. N. Engl. J. Med. 332:143-149.

45. Margolick, J.B., A.D. Donnenberg, A. Munoz, L.P. Park, K.D. Bauer, J.V. Giorgi, J. Ferbas, and A.J. Saah. 1993. Changes in T and non-T lymphocyte subsets following seroconversion to HIV-1: stable CD3+ and declining CD3populations suggest regulatory responses linked to loss of CD4 lymphocytes. The Multicenter AIDS Cohort Study. J. Acquir. Immune Defic. Syndr. 6:153-161.

46. Adleman, L.M., and D. Wofsy. 1993. T-cell homeostasis: implications in HIV infection [comment]. J. Acquir. Immune Defic. Syndr. 6:144-152.

47. Tough, D.F., P. Borrow, and J. Sprent. 1996. Induction of bystander T cell proliferation by viruses and type I interferon in vivo. Science (Wash. DC). 272:1947-1950.

48. Wang, Z.Q., A. Dudhane, T. Orlikowsky, K. Clarke, X. Li, Z Darzynkiewicz, and M.K. Hoffmann. 1994. CD4 engagement induces Fas antigendependent apoptosis of T cells in vivo. Eur. J. Immunol. 24:1549-1552.

49. Desbarats, J., J.H. Freed, P.A. Campbell, and M.K. Newell. 1996. Fas (CD95) expression and death-mediating function are induced by CD4 crosslinking on CD4+ T cells. Proc. Natl. Acad. Sci. USA. 93:11014-11018.

50. Jamali, I., E.H. Field, A. Fleming, and J.S. Cowdery. 1992. Kinetics of anti-CD4-induced $\mathrm{T}$ helper cell depletion and inhibition of function. Activation of $\mathrm{T}$ cells by the CD3 pathway inhibits anti-CD4-mediated $\mathrm{T}$ cell elimination and down-regulation of cell surface CD4. J. Immunol. 148:1613-1619.

51. Wang, Z.Q., A. Dudhane, T. Orlikowsky, and M.K. Hoffmann. 1995. T cell antigen receptor engagement abrogates CD4-mediated $\mathrm{T}$ cell deletion in vivo. Int. Immunol. 7:207-211.

52. Krammer, P.H., I. Behrmann, P. Daniel, J. Dhein, and K.M. Debatin. 1994. Regulation of apoptosis in the immune system. Curr. Opin. Immunol. 6 : 279-289.

53. Chace, J.H., J.S. Cowdery, and E.H. Field. 1994. Effect of anti-CD4 on CD4 subsets. I. Anti-CD4 preferentially deletes resting, naive CD4 cells and spares activated CD4 cells. J. Immunol. 152:405-412.

54. van der Lubbe, P.A., B.A.C. Dijkmans, H.M. Markusse, U. Nassander, and F.C. Breedveld. 1995. A randomized double-blind placebo-controlled study of CD4 monoclonal antibody therapy in early rheumatoid arthritis. Arthritis Rheum. 38:1097-1106.

55. Howie, S.E., A.J. Sommerfield, E. Gray, and D.J. Harrison. 1994. Peripheral T lymphocyte depletion by apoptosis after CD4 ligation in vivo: selective loss of CD44- and "activating" memory T cells. Clin. Exp. Immunol. 95 195-200.

56. O’Neill, J.K., D. Baker, A.N. Davison, S.J. Allen, C. Butter, H. Waldmann, and J.L. Turk. 1993. Control of immune-mediated disease of the central nervous system with monoclonal (CD4-specific) antibodies. J. Neuroimmunol. 45:1-14.

57. Ranges, G.E., S. Sriram, and S.M. Cooper. 1985. Prevention of type II collagen-induced arthritis by in vivo treatment with anti-L3T4. J. Exp. Med. 162:1105-1110.

58. Hom, J.T., L.D. Butler, P.E. Riedl, and A.M. Bendele. 1988. The progression of the inflammation in established collagen-induced arthritis can be altered by treatments with immunological or pharmacological agents which inhibit T cell activities. Eur. J. Immunol. 18:881-888. 